\title{
Leak testing of carbon-tin nanocomposites by thermal analysis methods
}

\author{
Agnieszka Chojnacka $^{1}$ - Marcin Molenda ${ }^{1} \cdot$ Dorota Majda $^{1} \cdot$ Piotr Natkański $^{1} \cdot$ \\ Roman Dziembaj ${ }^{1}$
}

Received: 28 October 2015/Accepted: 12 June 2016/Published online: 25 June 2016

(C) The Author(s) 2016. This article is published with open access at Springerlink.com

\begin{abstract}
Electrode materials consisted of tin nanograins encapsulated in different origin carbon buffer matrix (starch or water soluble polymer) were obtained in a simple and inexpensive process. The tin precursor was synthesized using modified reverse nanoemulsion technique (w/o) and then coated by a source of carbon. The composites precursors were pyrolysed, affording formation of $\mathrm{C} / \mathrm{Sn}$ anode materials. The resulting samples were investigated by powder X-ray diffraction studies in order to verify the structure and calculate crystallites sizes. The morphology of the nanocomposites was characterized by low-temperature nitrogen adsorption method $\left(\mathrm{N}_{2}-\mathrm{BET}\right)$. Thermal analysis measurements (EGA-TG/DTG/DTA and DSC) allowed determining optimal conditions of preparation process and estimating carbon content in the obtained anode materials. Thermogravimetric studies also proved to be highly useful in establishing the leak behaviour of $\mathrm{C} / \mathrm{Sn}$ nanocomposites. The electrochemical performance of the nanopowders was examined by charge-discharge tests in R2032-type coin cell. The thermal analysis results as well as low-temperature nitrogen adsorption data indicated that the origin of carbon precursor has major impact on morphology and leak behaviour of the obtained carbon buffer matrix. The electrochemical tests showed that better tightness of carbon-tin nanocomposites resulted in higher gravimetric capacity and better cell performance.
\end{abstract}

Marcin Molenda

molendam@chemia.uj.edu.pl

1 Faculty of Chemistry, Jagiellonian University, Ingardena 3, 30-060 Kraków, Poland
Keywords Li-ion batteries $\cdot \mathrm{C} / \mathrm{Sn}$ anodes $\cdot$ Carbon coating $\cdot$ Encapsulation $\cdot$ Leak testing

\section{Introduction}

In relation to the available anode materials for Li-ion batteries, tin has been shown as one of the best alternatives due to its lithium uptake at low potential and high theoretical capacity (994 $\mathrm{mAh} \mathrm{g}^{-1}$ for $\mathrm{Li}_{4.4} \mathrm{Sn}$ phase) [1]. However, the major problem during formation of $\mathrm{Li}_{\mathrm{x}} \mathrm{Sn}_{\mathrm{y}}$ alloys is cyclic volume changes of elementary cell, reaching up to $300 \%$ [2]. That process results in pulverization of the material which leads to the loss of electrical contact between active material and current collector, as well as physical damage of the cell, caused by high strains. The scientists are trying to overcome this issue by developing composites containing $\mathrm{Sn}$ and a stress-accommodating phase for instance graphene [3-5], carbon nanotubes [6-9], nanofibers $[10,11]$ or $\mathrm{TiO}_{2}$ nanotubes $[12,13]$. Nevertheless, the obtaining process of such materials is complicated and expensive. Therefore, noteworthy idea is development of tin-carbon nanocomposite, in which nanometric tin grains will be encapsulated in a flexible and conductive carbon buffer matrix using low-priced and easily accessible carbon source. Notwithstanding, such nanocomposites are able to provide appropriate electrochemical properties, only if the formed carbon matrix is leak-proof, flexible and optimally porous for $\mathrm{Li}^{+}$ions permeability, featuring local free space to compensate active material volume changes.

The goal of the present work was leak behaviour testing of two types carbon-tin nanocomposite anode materials using for the first time thermal analysis methods. The comparison of morphological and electrochemical properties of obtained $\mathrm{C} / \mathrm{Sn}$ anode materials was also discussed. 


\section{Experimental}

Two series of $\mathrm{C} / \mathrm{Sn}$ nanocomposites with different origin carbon buffer matrix were obtained. The nanometric precursor of active material $\left(\mathrm{SnO}_{2}\right)$ was prepared via modified reverse nanoemulsion method (w/o) for both series [14]. First series of the $\mathrm{C} / \mathrm{Sn}$ anode materials was obtained using the plant polysaccharide-potato starch (PS) as a carbon source. Details of the synthesis were described in our previous papers $[15,16]$. Briefly, $\mathrm{SnO}_{2}$ particles were coated by a potato starch in gelatinization process. Then the resulting $\mathrm{PS} / \mathrm{SnO}_{2}$ precursor was pyrolysed under argon flow (purity $99.999 \%, 3 \mathrm{dm}^{3} \mathrm{~h}^{-1}$ ) at $800{ }^{\circ} \mathrm{C}$ for $6 \mathrm{~h}$. The second series was prepared in the similar way, but the only difference was coating $\mathrm{SnO}_{2}$ by a polymer- $\operatorname{poly}(N$ - vinylformamide) modified with 5 mass $\%$ of pyromellitic acid (MPNVF) according to a procedure reported in Ref. $[17,18]$.

Optimal conditions of the pyrolysis were determined by thermogravimetric analysis (TG/DTG) using TGA/SDTA $851^{\mathrm{e}}$ Mettler-Toledo apparatus coupled with quadrupole mass spectrometer (QMS) ThermoStar GSD300T Balzers. The TG instrument was calibrated with indium, zinc and aluminium. Its accuracy is equal to $10^{-6} \mathrm{~g}$. The mass spectrometer was operated in electron impact mode (EI) using channeltron as a detector. Screening analyses were performed in the selected-ion monitoring (SIM) mode. The following ions' characteristics of each molecule, such as 17 for $\mathrm{OH}^{-}, \mathrm{NH}_{3}, 18$ for $\mathrm{H}_{2} \mathrm{O}, 28$ for $\mathrm{N}_{2}, \mathrm{CO}, 42$ for $\mathrm{C}_{3} \mathrm{H}_{6}$, $\mathrm{CH}_{2} \mathrm{CO}$ and 44 for $\mathrm{CO}_{2}$ were monitored. TG measurements
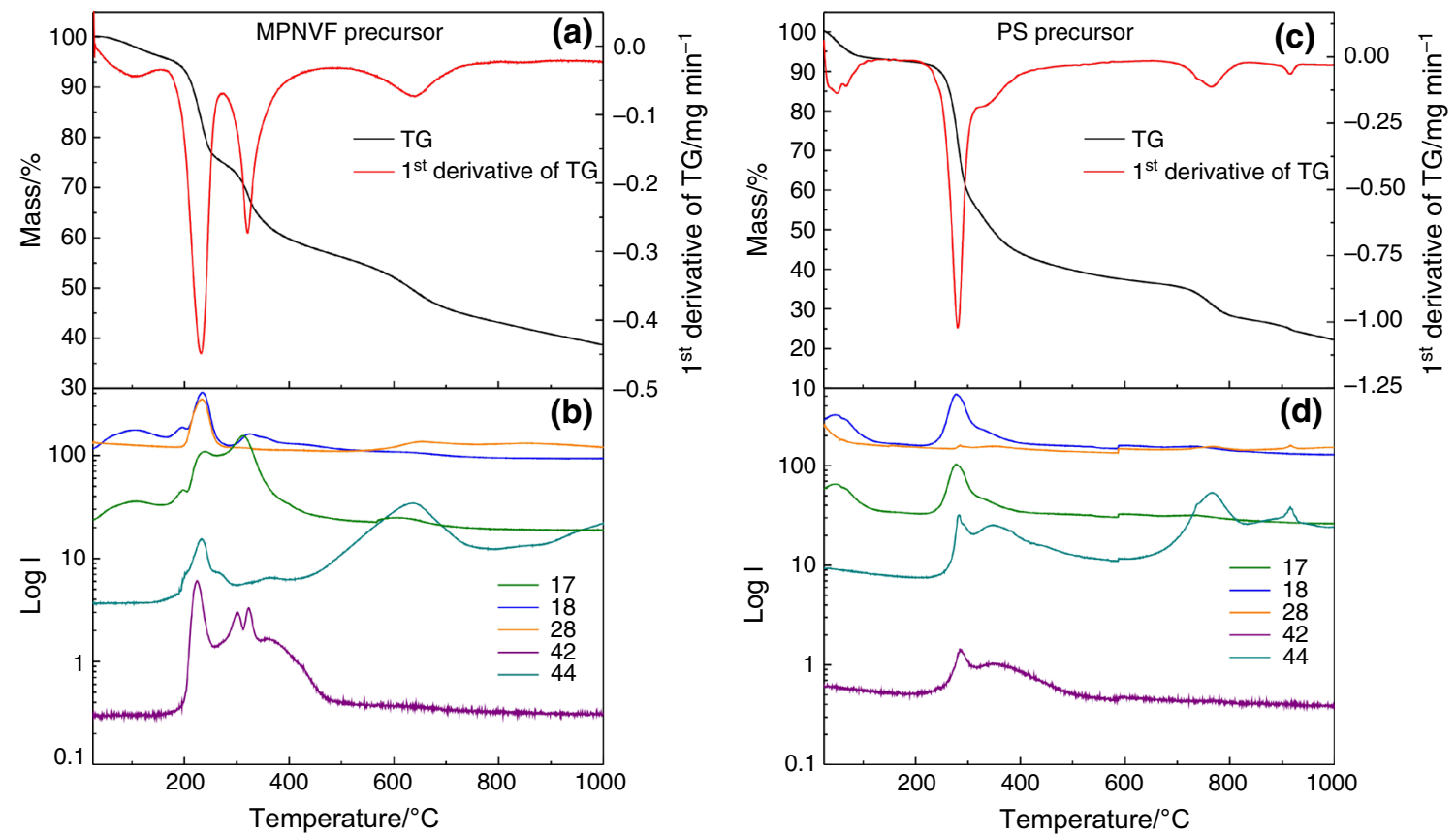

Fig. 1 Thermogravimetric studies (EGA-TG/DTG) of pyrolysis process of $\mathrm{MPNVF} / \mathrm{SnO}_{2}(\mathbf{a}, \mathbf{b})$ and $\mathrm{PS} / \mathrm{SnO}_{2}$ (c, d) composites precursors

Table 1 Carbon content in C/Sn nanocomposites and $\mathrm{Sn}$ melting process properties

\begin{tabular}{|c|c|c|c|c|}
\hline Sample & $\begin{array}{l}\text { Calculated carbon } \\
\text { content } / \%\end{array}$ & $\begin{array}{l}\text { Real carbon } \\
\text { content } / \%^{\mathrm{a}}\end{array}$ & $\begin{array}{l}\text { Melting } \\
\text { heat/J } \mathrm{g}^{-1 \mathrm{~b}}\end{array}$ & $\begin{array}{l}\text { Onset } \\
\text { temperature } /{ }^{\circ} \mathrm{C}^{\mathrm{b}}\end{array}$ \\
\hline $13 \% \mathrm{C} / \mathrm{Sn}$ MPNVF & 15 & 13 & 42.1 & 232 \\
\hline $32 \% \mathrm{C} / \mathrm{Sn}$ MPNVF & 30 & 32 & 25.1 & 233 \\
\hline $66 \%$ C/Sn MPNVF & 60 & 66 & 7.0 & 231 \\
\hline $15 \% \mathrm{C} / \mathrm{Sn} \mathrm{PS}$ & 15 & 15 & 21.6 & 231 \\
\hline $32 \% \mathrm{C} / \mathrm{Sn}$ PS & 30 & 32 & 18.3 & 231 \\
\hline $65 \% \mathrm{C} / \mathrm{Sn} \mathrm{PS}$ & 60 & 65 & 8.3 & 232 \\
\hline
\end{tabular}

\footnotetext{
${ }^{a}$ Evaluated by TG measurements

b Evaluated by DSC measurements
} 


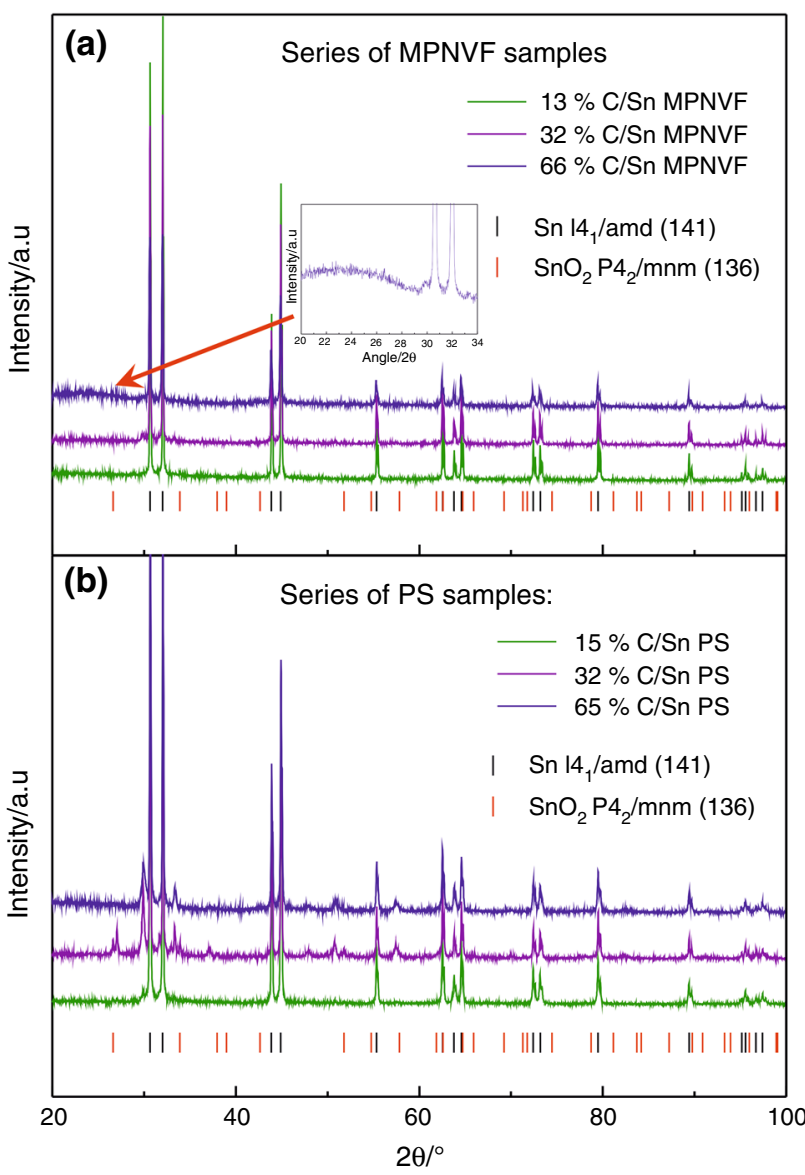

Fig. 2 X-ray powder diffraction (XRD) patterns for samples from the MPNVF (a) and PS (b) series

were taken in alumina crucibles under $4.8 \mathrm{dm}^{3} \mathrm{~h}^{-1}$ argon flow, within temperature range $30-1000{ }^{\circ} \mathrm{C}$ and heating rate $5{ }^{\circ} \mathrm{C} \mathrm{min}{ }^{-1}$. The material's weight was $10 \mathrm{mg}$.

The carbon content in the $\mathrm{C} / \mathrm{Sn}$ composites was determined by the temperature programmed oxidation (TPO) in air atmosphere using TA Instruments SDTA Q600 thermoanalyser. The instrument was calibrated with zinc. The measurements were taken with air flow of $4.8 \mathrm{dm}^{3} \mathrm{~h}^{-1}$ and heating rate of $5{ }^{\circ} \mathrm{C} \mathrm{min}^{-1}$, within temperature range $30-1000{ }^{\circ} \mathrm{C} .10 \mathrm{mg}$ of sample were used for analysis each time.
In order to describe the melting process of tin in resulting $\mathrm{C} / \mathrm{Sn}$ composites, the differential scanning calorimetry (DSC) using DSC $821^{\mathrm{e}}$ Mettler-Toledo equipment was performed. The instrument, which accuracy is equal to $10^{-6} \mathrm{~W}$, was calibrated with indium and zinc. The measurements were conducted in temperature range $150-300{ }^{\circ} \mathrm{C}$ under argon flow with scanning rate $5{ }^{\circ} \mathrm{C} \mathrm{min}^{-1}$ using aluminium pan. The empty crucible was used as the reference sample. The mass of the material was $10 \mathrm{mg}$.

Crystal structure of the C/Sn nanopowders was characterized by powder X-ray diffraction (XRD) with BRUKER D2 PHASER using $\mathrm{Cu} \mathrm{K \alpha}$ radiation $0.15418 \mathrm{~nm}$. The average size $\left(D_{\mathrm{XRD}}\right)$ of the tin nanograins was calculated using the Scherrer formula for (200), (101), (220) and (211) reflections.

The specific surface area $\left(S_{\mathrm{BET}}\right)$ and pore volume $\left(V_{\mathrm{P}}\right)$ of the composites were evaluated from $\mathrm{N}_{2}$ sorption at $-196{ }^{\circ} \mathrm{C}$ measured with 3Flex v1.00 (Micromeritics) automated gas adsorption system. Before the analysis, the samples were degassed under vacuum at $350{ }^{\circ} \mathrm{C}$ for $24 \mathrm{~h}$ using BET (Brunauer-Emmett-Teller) model. The average pore size $\left(D_{\mathrm{P}}\right)$ was determined by the single point adsorption at $p / p_{0}=0.98$.

Charge-discharge tests were performed in R2032-type coin cells $\left[\mathrm{Li} / \mathrm{Li}^{+} /(\mathrm{C} / \mathrm{Sn})\right]$ using $1 \mathrm{M} \mathrm{LiPF}_{6}$ solution in EC/DEC (1:1). The process of preparation working electrode was featured in previous paper [16]. Assembled cells were tested at a constant current density in the voltage range of $0.01-1.5 \mathrm{~V}$ at room temperature using ATLAS 0961 MBI multichannel battery testing system. The battery charging at $0.1 \mathrm{C}$-rate delivers its nominal evaluated capacity in $10 \mathrm{~h}$.

\section{Results and discussion}

The results of carbonization and carboreduction processes of the MPNVF/ $/ \mathrm{SnO}_{2}$ and $\mathrm{PS} / \mathrm{SnO}_{2}$ composites precursors performed in argon atmosphere are presented in Fig. 1. The EGA-TG/DTG curves for both samples indicate that the formation of $\mathrm{C} / \mathrm{Sn}$ composites ends at around $800{ }^{\circ} \mathrm{C}$;

Table 2 Crystallites size, specific surface area, pore volume and average pore size of the C/Sn nanocomposites

\begin{tabular}{llllc}
\hline Sample & $D_{\mathrm{XRD}} / \mathrm{nm}$ & $S_{\mathrm{BET}} / \mathrm{m}^{2} \mathrm{~g}^{-1}$ & $V_{\mathrm{P}} / \mathrm{cm}^{3} \mathrm{~g}^{-1}$ & 0.130 \\
\hline $13 \%$ C/Sn MPNVF & 60 & 155 & 0.125 & 3.3 \\
$32 \%$ C/Sn MPNVF & 56 & 243 & 0.155 & 2.1 \\
$66 \%$ C/Sn MPNVF & 51 & 299 & 0.156 & 3.1 \\
$15 \%$ C/Sn PS & 51 & 161 & 0.173 & 2.9 \\
$32 \%$ C/Sn PS & 54 & 241 & 0.174 & 1.8 \\
$65 \%$ C/Sn PS & 50 & 389 & & \\
\hline
\end{tabular}



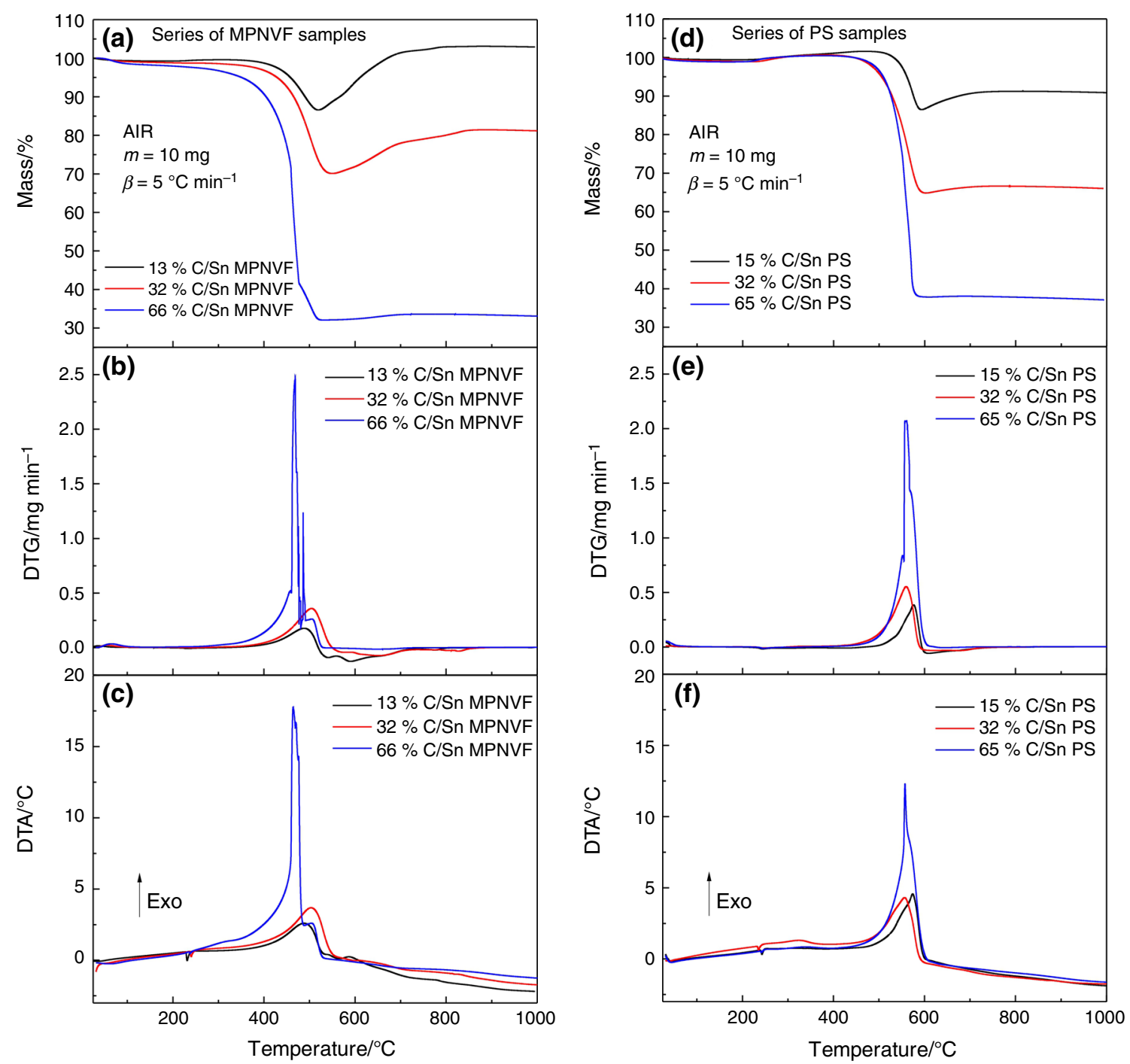

Fig. 3 Comparison of temperature programmed oxidation (TPO) process for materials from the MPNVF (a-c) and PS (d-f) series

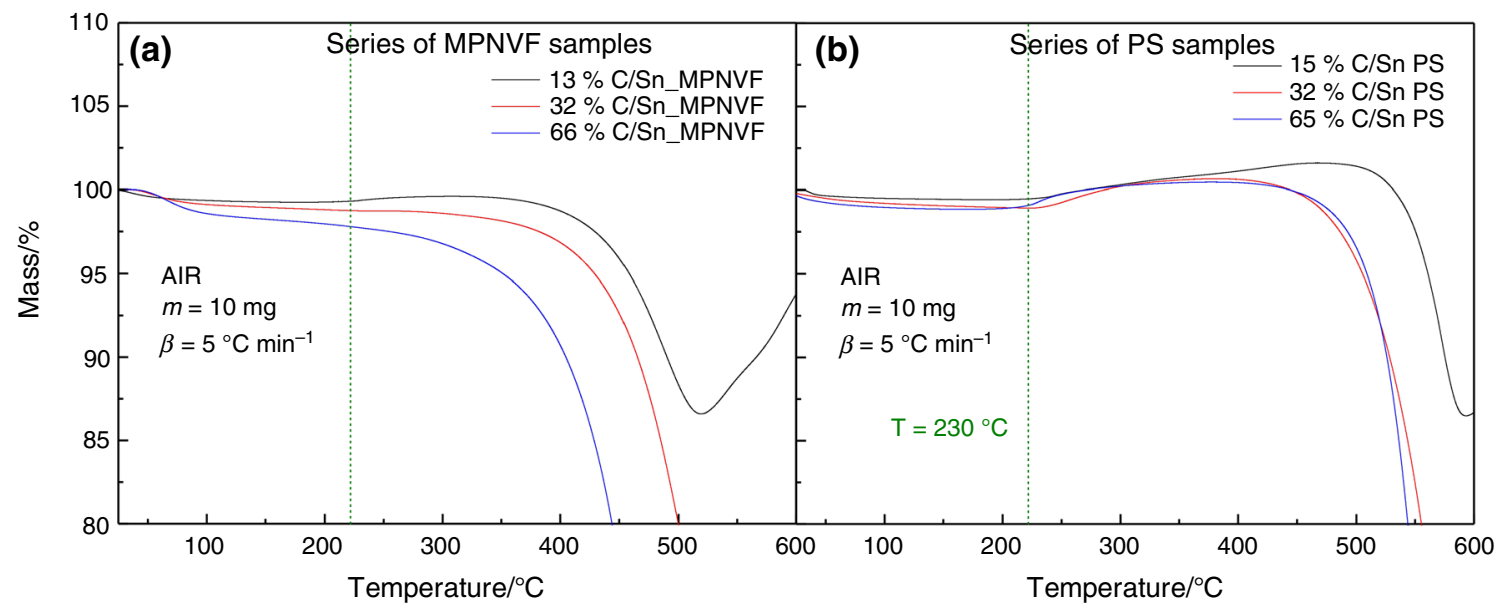

Fig. 4 Magnification of TG graphs from TPO process of samples from MPNVF (a) and PS (b) series 


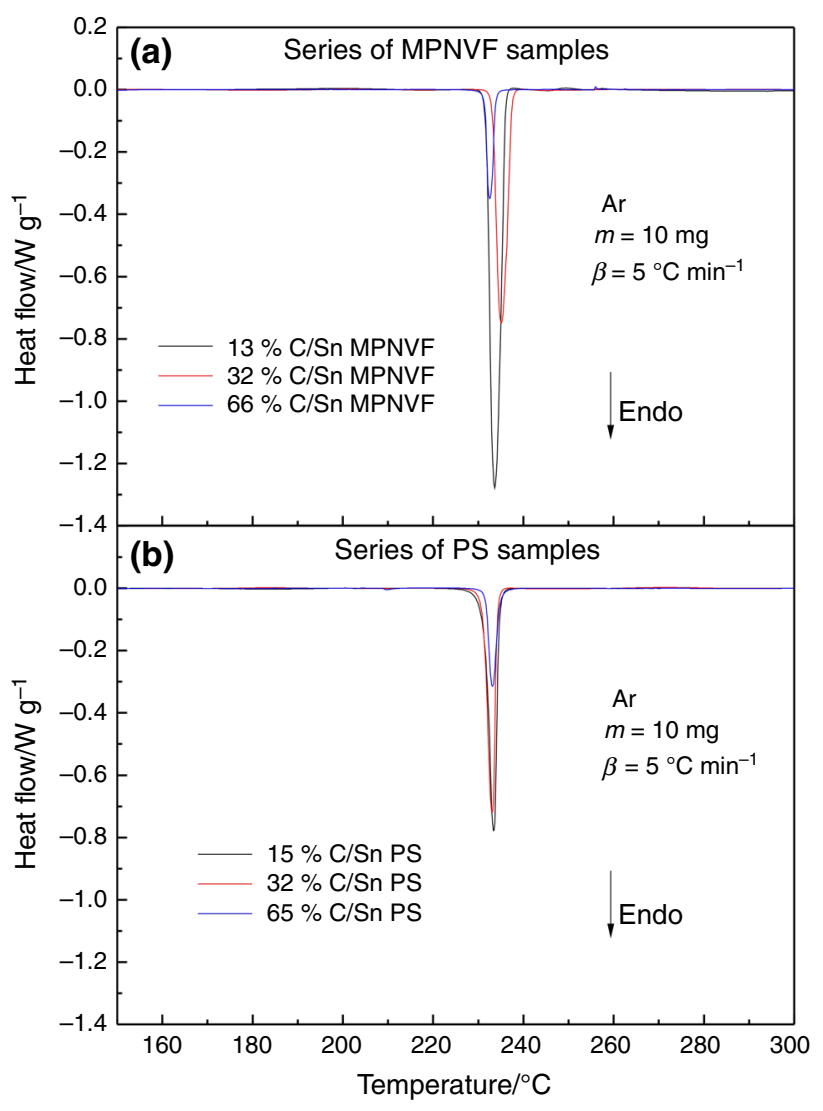

Fig. 5 Differential scanning calorimetry (DSC) of the melting process of tin in resulting nanocomposites from MPNVF (a) and PS (b) series

therefore, this temperature was selected as the temperature of pyrolysis for both series. However, it should be noticed that the obtainment of a $\mathrm{C} / \mathrm{Sn}$ compound varies significantly between the materials. For MPNVF series, this process is consisted of four stages. First one (also observed for PS series) is related to emission of water absorbed in the precursor's pores (Fig. $1 \mathrm{~b}-\mathrm{m} / \mathrm{z}$ lines 17 and 18 ). Higher decomposition loss occurs from $190{ }^{\circ} \mathrm{C}$ and is linked with carbonization process. It can be divided into two steps associated with splitting of $-\mathrm{NHCHO}$ groups from polymer [19]. The reduction of active material precursor $\left(\mathrm{SnO}_{2}\right)$ starts above $450{ }^{\circ} \mathrm{C}$, which is established by carbon dioxide evolution in the QMS curves (Fig. 1b). For PS series, formation of carbon begins from $250{ }^{\circ} \mathrm{C}$ and it is connected with decomposition of $-\mathrm{CHO}$ chains (Fig. 1d). Subsequently (from $725{ }^{\circ} \mathrm{C}$ ) the $\mathrm{SnO}_{2}$ carboreduction process is initiated.

The real values of carbon content in the obtained materials evaluated from TPO method are collected in Table 1. As it can be observed, estimated amount of carbon is close to the real values determined from thermogravimetric analysis.

The powder X-ray diffraction results of the $\mathrm{C} / \mathrm{Sn}$ nanocomposites are shown in Fig. 2. The XRD patterns indicate formation of tin cubic phase that belongs to I4 1 /amd space group (ICDD database, PDF-4 file \#00-0040673) in all presented composites. For the PS series, small amount of nanometric tin oxides corresponding to $\mathrm{P}_{2} / \mathrm{mnm}$ space group (ICDD database, PDF-4 file \#00041-1445) is also identified. Lack of significant reflexes associated with carbon material suggests that carbon buffer matrix is amorphous. Nonetheless, sample containing $66 \%$ of carbon from the MPNVF series reveals small hump in the place related to graphite, which can indicate that the graphitization degree (described as a ratio of disordered $s p^{3}$ to graphene-like $s p^{2}$ carbon) in this material is higher than in other samples. This observation is consistent with preliminary studies connected with pure carbon obtained from MPNVF precursor [19]. The crystallite sizes calculated for tin phase are collected in Table 2.

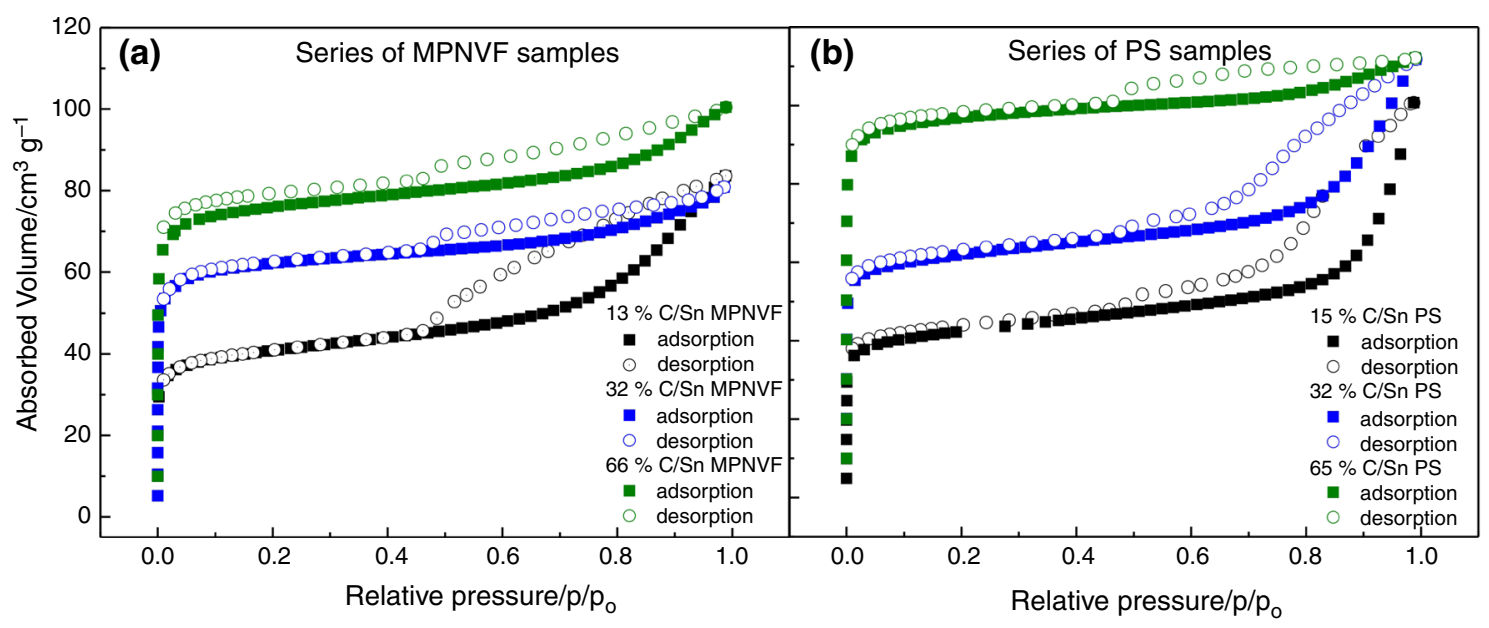

Fig. 6 Low-temperature nitrogen $\left(\mathrm{N}_{2}\right.$-BET) adsorption and desorption isotherms of nanopowders from MPNVF (a) and PS (b) series 
The TG/DTG/DTA measurements performed in the air are presented in Fig. 3. Depending on the series, TPO process starts at different temperatures. For MPNVF series, oxidation process may be divided into two stages. The first stage $\left(340-520^{\circ} \mathrm{C}\right)$ is accompanied with a strong exothermic effect (Fig. 3c), and it is related to carbon oxidation. It can be noticed that only for $66 \% \mathrm{C} / \mathrm{Sn}$ MPNVF sample this process includes two steps (Fig. 3a) which can indicate that in this material two types of carbon are present. It would be worthwhile to do further studies linked with detailed carbon description; however, that point is not the main goal of the presented paper. The second stage of TPO process for MPNVF series associated with mass increase $\left(520-800{ }^{\circ} \mathrm{C}\right)$ should be ascribed to tin oxidation. For PS series, TPO process consists of three stages. First one starts at $233{ }^{\circ} \mathrm{C}$ which is a value strongly connected to melting point of tin $\left(231.9^{\circ} \mathrm{C}\right)$ [20]. During this stage, tin in liquid state comes out through leaks in the material to the surface of the composite and oxidizes to $\mathrm{SnO}_{2}$. Magnification illustrated in Fig. $4 \mathrm{~b}$ clearly shows described process. This effect is not observed for the samples from the MPNVF series (Fig. 4a), which is the proof that the materials from PS series have to be leaking. The second stage of TPO for samples from PS series $\left(470-570{ }^{\circ} \mathrm{C}\right)$ is associated with exothermic carbon oxidation (Fig. 3f) and then $\left(570-750{ }^{\circ} \mathrm{C}\right)$ is related to tin oxidation. It should be also noticed that for the PS series, humps for the last step of the oxidation are smaller than for the MPNVF series due to earlier oxidation of tin on the composite's surface (Fig. 3a, d).

Detailed melting process of tin in resulting $\mathrm{C} / \mathrm{Sn}$ composites performed in argon flow is presented in Fig. 5. The onset temperatures of melting point are equal to literature value (Table 1). The melting heat increases with the higher content of tin in the composites, although for the MPNVF series the melting heat values are greater, which can also confirm that some of tin dioxides particles in composites precursors of PS series are not well encapsulated in carbon buffer matrix and have not been reduced during pyrolysis process. These results are also consistent with the XRD studies.

The difference in textural properties of both nanomaterials' series is shown in Fig. 6. All of the $\mathrm{N}_{2}$-BET isotherms belong to the type IV isotherms (IUPAC classification). For both series the surface area and pore volume increase with the higher carbon content in the samples (Table 2), which is also observed in Fig. 6 . Greater morphology parameters for PS series, especially

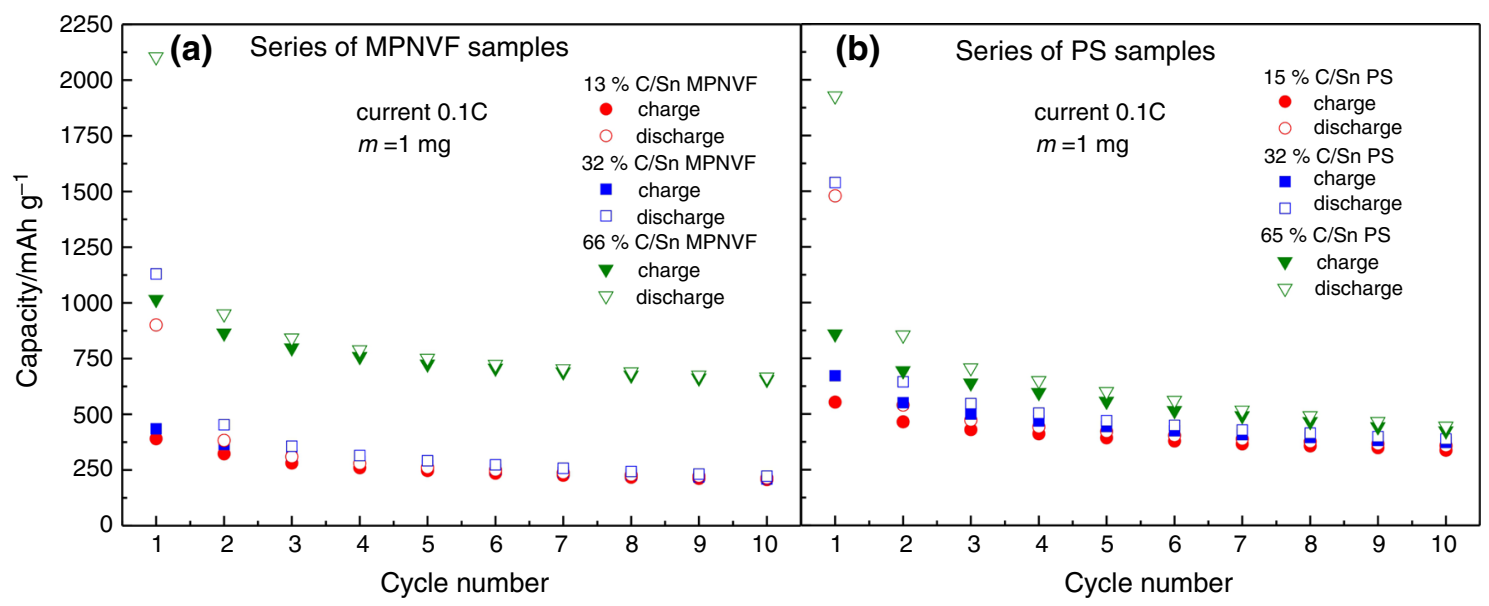

Fig. 7 Charge-discharge capacity of anode materials from MPNVF (a) and PS (b) series

Table 3 Comparison of specific charge capacities and efficiency for assembled cells

\begin{tabular}{|c|c|c|c|c|c|}
\hline \multirow[t]{2}{*}{ Sample } & \multirow{2}{*}{$\begin{array}{l}\text { After 1st cycle } \\
\text { Charge capacity/ } \\
\text { mAh g }^{-1}\end{array}$} & \multicolumn{2}{|l|}{ After 5th cycle } & \multicolumn{2}{|l|}{ After 10th cycle } \\
\hline & & $\begin{array}{l}\text { Charge capacity/ } \\
\mathrm{mAh} \mathrm{g}^{-1}\end{array}$ & $\begin{array}{l}\text { Cell efficiency/ } \\
\%\end{array}$ & $\begin{array}{l}\text { Charge capacity/ } \\
\mathrm{mAh} \mathrm{g}^{-1}\end{array}$ & $\begin{array}{l}\text { Cell efficiency/ } \\
\%\end{array}$ \\
\hline $66 \% \mathrm{C} / \mathrm{Sn}$ MPNVF & 1015 & 726 & 71 & 657 & 65 \\
\hline $65 \% \mathrm{C} / \mathrm{Sn}$ PS & 860 & 557 & 65 & 424 & 49 \\
\hline
\end{tabular}


linearly increasing specific surface area together with carbon content and large pore volume, reveal that for PS compounds the pores are open through the composite. That also implies that the carbon matrix in PS series is leakiness.

The comparison of electrochemical performance for cells assembled using materials from both series is presented in Fig. 7. The detailed data associated with specific charge capacity of the best electrochemical working cells from both series are collected in Table 3. In line with expectation, the best electrochemical performance demonstrates electrode containing $66 \% \mathrm{C} / \mathrm{Sn}$ MPNVF anode material (Fig. 7a). The results suggest that the higher carbon loading in the $\mathrm{C} / \mathrm{Sn}$ nanocomposites provides effective protection against the active material volume expansion which is reflected in higher capacity in chargedischarge tests. That observation also complies with our previous studies [16].

\section{Conclusions}

The leak-testing studies of $\mathrm{C} / \mathrm{Sn}$ nanocomposites were performed using for the first time thermal analysis methods (TG/DTG/DTA and DSC). Obtained thermogravimetric results highlight the important role of the origin of carbon buffer matrix. The TPO method showed that samples from PS series demonstrate high level of leaks in the examined materials. High values of specific surface area, as well as pore volume for PS series, reveal presence of the open pores through the composites. Those observations were confirmed by the low-temperature nitrogen adsorption $\left(\mathrm{N}_{2}-\mathrm{BET}\right)$.

The results linked with specific charge capacity of investigated cells indicate that carbon source has also a significant impact on the electrochemical performance of the assembled batteries, especially gravimetric capacity and cell efficiency. The $66 \% \mathrm{C} / \mathrm{Sn}$ electrode material from the MPNVF series exhibits better cycling performance (657 $\mathrm{mAh} \mathrm{g}^{-1}$ after 10 cycles) than the corresponding $65 \% \mathrm{C} / \mathrm{Sn}$ material from the PS series $\left(424 \mathrm{mAh} \mathrm{g}^{-1}\right.$ after 10 cycles) which correlates with conducted thermal and morphology studies.

Acknowledgements The authors acknowledge a financial support from the National Science Centre of Poland under research Grant No. 2012/07/N/ST8/03725.

Open Access This article is distributed under the terms of the Creative Commons Attribution 4.0 International License (http://crea tivecommons.org/licenses/by/4.0/), which permits unrestricted use, distribution, and reproduction in any medium, provided you give appropriate credit to the original author(s) and the source, provide a link to the Creative Commons license, and indicate if changes were made.

\section{References}

1. Zheng T, Dahn J. Applications of carbon in lithium ion batteries, carbon materials for advanced technologies. 1st ed. Oxford: Elsevier; 1999.

2. Winter M, Besenhard JO. Electrochemical lithiation of tin and tin-based intermetallics and composites. Electrochim Acta. 1999;45:31-50.

3. Wu Q-H, Wang C, Ren J-G. Sn and $\mathrm{SnO}_{2}$-graphene composites as anode materials for lithium-ion batteries. Ionics. 2013;19:1875-82.

4. Berlia R, Kumar MKP, Srivastava Ch. Electrochemical behavior of Sn-graphene composite coating. RSC Adv. 2015;5:71413-8.

5. Wu Ch, Maier J, Yu Y. Sn-based nanoparticles encapsulated in a porous 3D graphene network: advanced anodes for high-rate and long life Li-ion batteries. Adv Funct Mater. 2015;25:3488-96.

6. Uysal M, Cetinkaya T, Alp A, Akbulut H. Production of Sn/ MWCNT nanocomposite anodes by pulse electrodeposition for Li-ion batteries. Appl Surf Sci. 2014;290:6-12.

7. Liu C-J, Huanga H, Cao G-Z, Xue F-H, Camacho RAP, Dong $\mathrm{X}$-L. Enhanced electrochemical stability of Sn-carbon nanotube nanocapsules as lithium-ion battery anode. Electrochim Acta. 2014;144:376-82.

8. Zhong Y, Li X, Zhang Y, Li R, Cai M, Sun X. Nanostructured coreshell Sn nanowires@ CNTs with controllable thickness of CNT shells for lithium ion battery. Appl Surf Sci. 2015;332:192-7.

9. Sun L, Wang X, Susantyoko RA, Zhang Q. High performance binder-free $\mathrm{Sn}$ coated carbon nanotube array anode. Carbon. 2015;82:282-7.

10. Nam D-H, Kim JW, Lee J-H, Lee S-Y, Shin H-A-S, Lee S-H, Joo Y-C. Tunable Sn structures in porosity-controlled carbon nanofibers for all-solid-state lithium-ion battery anodes. J Mater Chem A. 2015;3:11021-30.

11. Shen Z, Hu Y, Chen Y, Zhang X, Wang K, Chen R. Tin nanoparticle-loaded porous carbon nanofiber composite anodes for high current lithium-ion batteries. J Power Sources. 2015;278:660-7.

12. Kim HS, Yu S-H, Cho Y-H, Kang SH, Sung Y-E. $\mathrm{TiO}_{2}$-core/Snshell nanotube arrays based on monolithic negative electrode for Li-ion batteries. Electrochim Acta. 2014;130:600-5.

13. Yu C, Bai Y, Yan D, Li X, Zhang W. Improved electrochemical properties of Sn-doped $\mathrm{TiO}_{2}$ nanotube as an anode material for lithium ion battery. J Solid State Electrochem. 2014;18:1933-40.

14. Molenda M. Carbon electrode composites for Li-ion batteries prepared from polymer precursors. Funct Mater Lett. 2011;4:129-34.

15. Chojnacka A, Molenda M, Bakierska M, Dziembaj R. Novel method of preparation of $\mathrm{C} / \mathrm{Sn}-\mathrm{SnO}_{2}$ nanocomposite $\mathrm{Li}$-ion anode material derived from plant polysaccharides. Procedia Eng. 2014;98:2-7.

16. Chojnacka A, Molenda M, Bakierska M, Dziembaj R. Electrochemical performance of $\mathrm{Sn} / \mathrm{SnO}_{2}$ nanoparticles encapsulated in carbon matrix derived from plant polysaccharides. ECS Trans. 2015;64(22):165-71.

17. Molenda M, Chojnacka A, Bakierska M, Dziembaj R. Facile synthesis of $\mathrm{C} / \mathrm{Sn}$ nanocomposite anode material for $\mathrm{Li}$ ion batteries. Mater Technol. 2014;29(A2):A88-92.

18. Molenda M, Dziembaj R, Kochanowski A, Bortel E, Drozdek M, Piwowarska Z. Process for the preparation of conductive carbon layers on powdered supports. PAT. 216549; US patent application 20110151112. 2014.

19. Molenda M, Chojnacka A, Natkański P, Podstawka-Proniewicz E, Kuśtrowski P, Dziembaj R. Pyrolytic carbons derived from water soluble polymers. J Therm Anal Calorim. 2013;113:329-34.

20. Daniel C, Besenhard JO. Handbook of battery materials. 2nd ed. Germany: Wiley-VCH; 2011. 